\title{
The Hormonal Milieu in Primary Breast Cancer: A Correlation Between Steroid Receptors and Serum Estradiol, Progesterone and Prolactin
}

\author{
Mehryar Zargari \\ Department of Biochemistry, Molecular and Cell Biology Research Center, Faculty of Medicine, Mazandaran University of Medical Sciences, \\ Sari, Iran.
}

Received: 5 Mar 2013

Revised : 27 Apr 2013

Accepted: 5 Sep 2013

Corresponding Author: Mehryar Zargari

Department of Bichemistry, Faculty of Medicine, Mazandaran University of

Medical Sciences, Sari, Iran

Phone: +98-113543081

E-mail: zargari.mehryar@gmail.com

\begin{abstract}
Background: The female breast is subjected to a life time of hormonal controls, whose effect is evident at the time of menarche and during the menstrual cycle, pregnancy and lactation. Studies have reported multiple risk factors for breast cancer, some of which are a reflection of hormonally mediated events. The steroid receptors are also served as prognostic factors for evaluating the status of malignant tumor of the breast. Estrogen receptor (ER) and progesterone receptor (PgR) formation are influenced by estrogen and progesterone concentration. The aim of this study was to clarify the hormonal milieu of the breast cancer such as Estradiol (E2), Progesterone (Pg), Prolactin (PRL) and their correlation with prognostic factors like ER, PgR.

Materials and Methods: In this study, we examined fourthy-four samples removed from patients with primary breast cancer by radical mastectomy. The specimens include thirty six malignant and eight benign breast tissues. Blood samples were also obtained before surgery. Steroid receptors was assayed by the method of single-point dextrane-coated charcoal (DCC), hormones by radioimmunoassay.

Results: The beating area percentage of EBs in OT treatment group was more than that of the $5 \mathrm{Az}$ group in all days of experiment. However, only in final stage, a significant increase was observed in beating area of OT group. There was no significant difference in viability and morphological changes. OT induction expressed three more specific proteins in cell culture than $5 \mathrm{Az}$.

Conclusion: Statistical analysis revealed that response to OT inducer was more excessive than $5 \mathrm{Az}$ in all treatment groups. The Oxytocin was found to be effective inducer of cardiomyocytes differentiation from embryonic carcinoma cells P19 than 5-azacytidine.
\end{abstract}

Keywords: P19 Cells; Embryoid Bodies; Cardiomyocytes; 5-Azacytidin; Oxytocin; Differentiation

Please cite this article as: Zargary M. The Hormonal Milieu in Primary Breast Cancer: A Correlation Between Steroid Receptors and Serum Estradiol, Progesterone and Prolactin. Res Mol Med. 2013; 1 (2): 44-47

\section{Introduction}

Breast cancer is one of the prevalent cancers in females and the second cause of death with the rate of $18 \%$ after lung cancer (1) and in European women; it is responsible for $27 \%$ of all new cases and $17 \%$ of cancer deaths (2-3). Environmental, genetical and especially endocrine factors play important role in breast cancer. Researchers showed that age of menstrual cycle, menopause (4-5), late age of pregnancy (6), oral use of contraceptive at low age for at least 8-10 years (7), fattiness in female at the age of menopause (8) probably would cause breast cancer. No doubt steroid hormones are involved in the development of breast cancer. Experimental data from animal models suggest that the use of estrogen can cause neoplasma (9). Study of human breast cancer cell lines in vitro, with the use of estrogen 
alone or in combination with other hormones showed an increase in malignancy (10). Prolactin probably would helps in the development of breast tumors (11), because substances which enhance the secretion of prolactin cause tumor growth. For example perfenazine would enhances the secretion of prolactin and finally an increase in number and size of tumor in animal experiments that lack adrenal gland and ovary $(12,13)$. Also, haloperidol and methyl dopa could enhnce tumor growth stimulated by dimethyl benzaantrasen (DMBA) by enhancement of prolactin secretion (14). In breast cancer, prognosis is very important. The researchers attempted to identify the predictors of patients who respond to hormone therapy. Many results of which show an interesting relationship between estrogen and progesterone receptors and clinical association of breast cancer. The fact that the patients who have tumors containing receptors, would showed prolonged survival and disease-free time than patients without those receptors (15). In other words, receptor status, lymph nodes, grade of tumor can be used as an important prognostic indicator in management and treatment of breast cancer.

The aim of this study was to assay estradiol, progesterone and prolactin concentration in serum and the status of estrogen and progesterone receptors of tumors as a prognostic factor due to the role of hormones in the control of carcinogenic cells and their part in the production of estrogenic and progestonic receptors.

\section{Materials and Methods}

A total of 44 female patients with primary breast carcinoma were enrolled and treated by radical mastectomy at the immamkhomini, day and firuzgar hospital in Tehran. The spciements include 36 malignant tumor, 8 benign breast tissue. Immediately after surgery, approximately 0.5 gr of cacerous tissue was collected in liquid nitrogen tank. Tumors were stored at $-80{ }^{\circ} \mathrm{C}$ until the assay was performed. The frozen tumor was stripped of adherent fat and then cut into small blocks and then pulverized in microdismembrator (Boran-Germany) and homogenized in cold TEDG buffer (10mM tris; 1mM EDTA; $0.5 \mathrm{mM}$
Dithiotritol and glycerol $10 \%, \mathrm{pH}=7.4)$ at the ratio 1:4 (w/v). the homogenate was centrifuged by ultracentrifuge (Sorval otd combi) at $100000 \mathrm{~g}$ and $4{ }^{\circ} \mathrm{C}$ for 60 minute to obtain a cytosol fraction which was assayed for ER, PgR and protein concentration.

The cytosol was examined for ER and PgR by the method of DCC (16-17). In this method cytosol incubated with $17 \beta-[2,4,6,7-3 \mathrm{H}]$ estradiol (SP.activity $83 \mathrm{ci} / \mathrm{mmol}$ ) and $[2,4,6,7-3 \mathrm{H}]$ progesterone (SP.activity $92 \mathrm{ci} / \mathrm{mmol}$ ) repectively. Balnks of each of the above mixtures, without protein, were also prepared. Tests were performed in duplicate and incubate at $0-4{ }^{\circ} \mathrm{C}$ for $18-20$ hours. Unbound hormone was removed by $10 \mathrm{~min}$ incubation with suspension of charcoal-Dextran T-70 in TEDG buffer at $4{ }^{\circ} \mathrm{C}$. Dextran-Charcoal was removed at $4000 \mathrm{rpm}$ for $10 \mathrm{~min}$. $200 \mu \mathrm{l}$ of supernatant was mixed with $4 \mathrm{ml}$ scintillation cocktail and after 24 hour counted with beta-counter (LKB-1410). Results of specific binding was expressed in $\mathrm{fmol} / \mathrm{mg}$ protein.protein content of the cytosol was determined by the method of Bradford (18). ER and PgR considered positive if the values were equal to or greater than 10 and $5 \mathrm{fmol} / \mathrm{mg}$ cytosol protein, respectively.

Blood samples were also obtained before surgery. After centrifuge at $1500 \mathrm{~g}$, aliqut of serum stored at $70{ }^{\circ} \mathrm{C}$ until was assayed by radioimmunoassay to determine hormones level. Statistical analyses were performed using X2 test and nonparametric manwhitney \& sperman rank test.

\section{Results}

The patients in this study were between 25 and 75 years of age. $66 \%$ of them were more than 45 years old and most of them were more than 60 years old. Out of 36 malignant tumor cases 18 patients were at the age of menopause and the rest in post-menopause period. The grading of disease were as follow: 10 (grade III), 23 (grade II) and 1 (grade I). On the basis of histology data $83.4 \%$ were in invasive ductal carcinoma. The rate of $\mathrm{ER}$ and $\mathrm{PgR}$ in malignant tumorwere as follow $1.4-93 \mathrm{fmol} / \mathrm{mg}$ and $0.63-59.5$ $\mathrm{fmol} / \mathrm{mg}$ protein respectively (Table 1-2).

Table 1. Status of receptors in age groups.

\begin{tabular}{lllll}
\hline Receptor & $<\mathbf{4 1}$ & $\mathbf{4 1 - 5 0}$ & $\mathbf{5 1 - 6 0}$ & $>\mathbf{6 1}$ \\
\hline $\mathbf{E R}^{+}(\boldsymbol{\%})$ & $55(5 / 9)$ & $44(4 / 9)$ & $100(9 / 9)$ & $77(7 / 9)$ \\
$\mathbf{P g R}^{+}(\boldsymbol{\%})$ & $44(4 / 9)$ & $23(2 / 9)$ & $66(6 / 9)$ & $88(8 / 9)$ \\
$\mathbf{E R}^{+}$ & $23.84 \pm 12.98$ & $21.33 \pm 8.87$ & $40.62 \pm 22.15$ & $36.49 \pm 15.04$ \\
$\mathbf{P g R}^{+}$ & $18.79 \pm 14.8$ & $35.66 \pm 24.24$ & $15.11 \pm 5.91$ & $20.73 \pm 12.75$ \\
\hline
\end{tabular}


The rate of serum prolactin was 7.4-443 $\mathrm{ng} / \mathrm{ml}$ with the mean of $184 \pm 109 \mathrm{ng} / \mathrm{ml}$ (high difference with normal value: $0.3-20.8$ ). But there was no significant correlation with receptors (data not shown).

Table 2. Status of receptors in malignant tumor.

\begin{tabular}{llll}
\hline Receptor & Total percent & Premenopause & Postmenopause \\
\hline $\mathrm{ER}^{+}$ & 69 & $50 \%(9 / 18)$ & $88 \%(16 / 18)$ \\
$\mathrm{PgR}^{+}$ & 55 & $33 \%(6 / 18)$ & $66 \%(12 / 18)$ \\
$\mathrm{ER}^{+}, \mathrm{PgR}^{+}$ & 47 & $22 \%(4 / 18)$ & $72 \%(13 / 18)$ \\
$\mathrm{ER}^{+}, \mathrm{PgR}^{-}$ & 22 & $28 \%(5 / 18)$ & $17 \%(3 / 18)$ \\
$\mathrm{ER}^{-}, \mathrm{PgR}^{+}$ & 8.3 & $11 \%(2 / 18)$ & $5 \%(1 / 18)$ \\
$\mathrm{ER}^{-}, \mathrm{PgR}^{-}$ & 22 & $39 \%(7 / 18)$ & $5 \%(1 / 18)$ \\
\hline
\end{tabular}

Serum prolactin was partially more in G.III (208 \pm 111 to G.II $(183 \pm 107)$ but there is no significant difference $(p>0.2)$. Serum estradiol in two groups of PgR- and PgR+ was studied. It was found that it was more in $\mathrm{PgR}+$ to $\mathrm{PgR}-(\mathrm{p}<0.003)$. frequency of $\mathrm{PgR}+$ in patients with estradiol serum of less and more than $10 \mathrm{pg} / \mathrm{ml}$ were $18 \%$ and $42 \%$ respectively. Also studying of serum progesterone status in $\mathrm{PgR}+$ and $\mathrm{PgR}$ - groups showed that the rate of $\mathrm{Pg}$ in $\mathrm{PgR}+$ was less than PgR- $(p<0.01)$.frequency of $\mathrm{PgR}+$ tumors in the serum pg group more and less than $1.5 \mathrm{ng} / \mathrm{ml}$ was $41 \%$ and $61 \%$ respectively (Figure $1-2$ ).

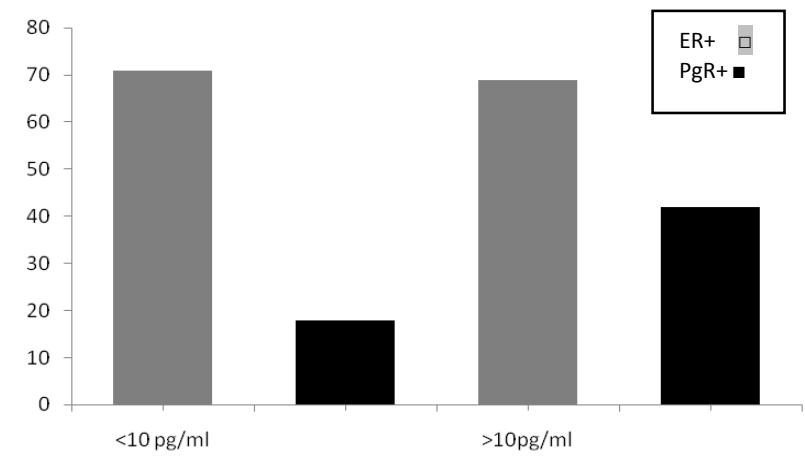

Figure 1. Frequency of ER+ and PgR + in two group (serum E2 more and less than $10 \mathrm{pg} / \mathrm{ml}$ ).

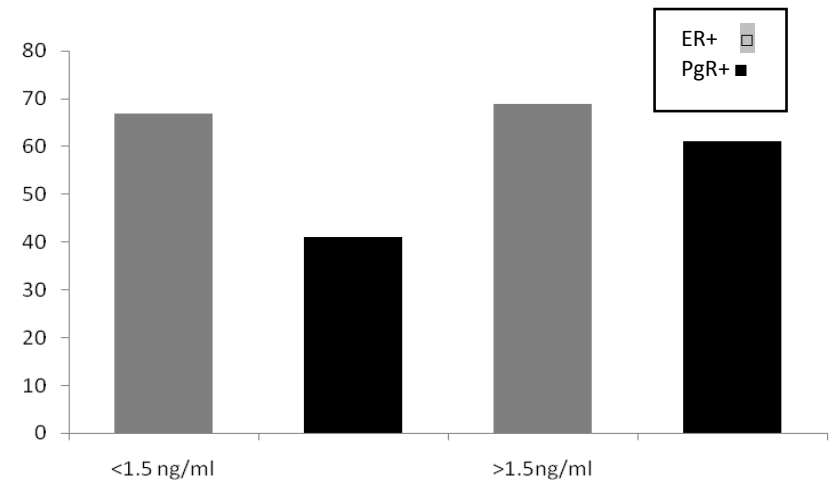

Figure 2. Frequency of ER+ and PgR+ in two group (serum Pg more and less than $1.5 \mathrm{ng} / \mathrm{ml}$ ).
Breast cancer is one of the most prevalent cancer in females, so, many laboratories test have been done.

Type of diet, reproductive templates and altered exposure to endogenous and exogenous compounds with hormonal activity have been suggested as increasing this status (19). Prognosis and treatment of breast cancer is determined by the stage of illness, which is estimated gold standard items such as grade, tumor size and lymph node contribution (20). We showed that frequency of ER and $\mathrm{PgR}$ in postmenopause is more than premenopause $(\mathrm{p}<0.05)$. Our finding is similar to finding by other researchers $(21,22,23)$. To justify this Subject, it is believe that the induction of ER and PgR is controlled by down regulation mechanism that caused by progesterone hormone. After menopause, production of $\mathrm{Pg}$ decreased and the depressing effect on the production of these receptors was lacked. Furthermore the quantity of accessible free receptor is reduced, because E2 hormone in blood is high at premenopause and occupied the receptors $(21,24$, 25 ). It has been shown that by approximately $60 \%$ of the tumors in the presence of estrogen receptor in tumors, will response to hormone therapy and when both are present in $80 \%$ of the, tumors respond to this type of treatment (26).

There were no statistically significant difference between the variation of E2 and Pg with the quantity of ER, but the the quantity of PgR was related positively to E2 hormone and negatively to $\mathrm{Pg}$ hormone $(\mathrm{p}<0.05)$. We could suggested that induction of PgR stimulate by E2 but inhibit by Pg. Mehata and co-workers also did not find any communication between estradiol and estrogenic receptors in tumoral tissue (27) but drafta showed high levels of estradiol and estrone in blood and E2 in cytosol that associated with increasing of ER frequency (28).

Prolactin, a polypeptide hormone, is essential for mammary gland development and lactation. In animals, prolactin is important in mammary epithelial development; administration of exogenous prolactin increases rates of mammary tumor formation and 
suppression of prolactin levels decreases tumor formation (29). We observed a high levels of plasma prolactin and subsequent in benign and malignant tumors. Due to the high amount of prolactin in both benign and malignant than normal, it could be suggested to as a etiologic factor in early detection of the cancer. Because of relatively high prolactin contained in the serum possibly can be drawn from the origin of the tumor.

\section{References}

1. Silverberg, E, Lubera J. Cancer statistics. CA Cancer J Clin. 1987; 37 (1): 2-19. PMID: 3099992.

2. Tyczynski JE, Plesko I, Aareleid T, Primic-Zakelj M, Dalmas $\mathrm{M}$, Kurtinaitis J, et al. Breast cancer mortality patterns and time trends in 10 new EU member states: mortality declining in young women, but still increasing in the elderly. Int J Can. 2004; 112 (6): 1056-64. PMID: 15386350

3. Boyle P, Ferlay J. Cancer incidence and mortality in Europe Ann Oncol. 2004; 16 (3): 481-8. PMID: 15718248

4. Lynch HT, Watson P, Conway TA, Lynch JF. Natural history and age at onset of hereditary breast cancer. Cancer. 1992; 69 (6): 1404-407. PMID: 1540877

5. Marrow M. Identification management of the women at increased risk for breast cancer development. Breast Cancer Res Treat. 1994; 31 (1): 53-60. PMID: 7981457

6. Smith EL, Hill RL, Lehman IR, Lefkowitz RJ, Handler PA. White Principles of Biochemistry. 1983: 482.

7. Murray K. Harper's Illustrated Biochemistry. 2009: 472.

8. Den Tonkelaar I, Seidell JC, Collette HJ, de Waard F. Obesity and subcutaneous fat patterning in relation to breast cancer in postmenopausal women participating in the Diagnostic Investigation of Mammary Cancer Project. Cancer. 1992; 69 (11): 2663-2667. PMID: 1571895

9. Chlebowski RT, Hendrix SL, Langer RD, Stefanick ML, Gass $\mathrm{M}$, Lane D, et al. Influence of estrogen plus progestin on breast cancer and mammography in healthy postmenopausal women. JAMA. 2003; 289 (24): 3243-53. PMID: 12824205

10. Tamimi RM, Hankinson SE, Chen WY, Rosner B, Colditz GA. Combined estrogen and testosterone use and risk of breast cancer in postmenopausal women. Arch Intern Med. 2006; 166 (14): 1483-9. PMID: 16864758

11. Smithline F, Sherman L, Kolodny D. Prolactin and breast carcinoma. N Engl J Med. 1975; 292 (15): 784-92. PMID: 1089886

12. Pearson $\mathrm{OH}$, Llerena $\mathrm{O}$, Llerena L, Molina A, Butler $\mathrm{T}$. Prolactin-dependent rat mammary cancer: a model for man? Trans Assoc Am Physicians. 1969; 82: 225-38. PMID: 5375151

13. Nagasawa H, Yanai R. Effects of prolactin or growth hormone on growth of carcinogen-induced mammary tumors of adrenoovariectomized rats. Int J Cancer. 1970; 6 (3): 488-95. PMID: 5486607

14. Quadri S.K, JL Clark, J Meites. Effects of LSD, pargyline and haloperidol on mammary tumor growth in rats. Proc Soc Exp Biol Med. 1973; 142 (1): 22-6. PMID: 4683245

15. Baum M. Achieving a biological profile of the breast cancer patient. Experientia Suppl. 1982; 41: 69-85. PMID: 6958541

16. McGurie WL, De La Garza M, Chamness GC. Evaluation of estrogen receptor assay in human breast tissue. Cancer Res. 1977; 37 (3): 637-9. PMID: 837364

17. Pichon MF, Milgrom E. Characterization and assay of progesterone receptor in human mammary carcinoma. Cancer Res. 1977; 37 (2): 464-71. PMID: 832270

18. Bradford MM. A rapid and sensitive method for the quantitation of microgram quantities of protein utilizing the principle of protein-dye binding. Anal Biochem. 1976; 72: 248-54. PMID: 942051

19. Weiss HA, Potischman NA, Brinton LA, Brogan D, Coates RJ, Gammon MD, et al. Prenatal and perinatal risk factors for breast cancer in young women. Epidemiology. 1997; 8: 181-187. PMID: 9229211

20. Hlupić L, Jakić-Razumović J, Bozikov J, Corić M, Belev B, Vrbanec D. Prognostic value of different factors in breast carcinoma. Tumori. 2004; 90 (1): 112-19. PMID: 15143983

21. Seibert K, Lippman ME. Hormone receptors in breast cancer In: Baum M, editor. Clinical Oncology. Volume 1. London (UK): WB Saunders Company. 1982; 735-61.

22. Hashemi M, Karami Tehrani F. Estrogen and Progesterone receptor status in tumor samples of Iranian breast cancer patients. Pak J Biol Sci. 2006; 9 (5): 854-8.

23. Elwood JM, Godolphin W. Oestrogen receptors in breast tumours: associations with age, menopausal status and epidemiological and clinical features in 735 patients. $\mathrm{Br} \mathrm{j}$ cancer. 1980; 42 (5): 635-44. PMID: 7459204

24. Saez S, Chouvet C. Influence of endogenous hormone levels on tumor estradiol and progesterone receptors. Recent Results Cancer Res. 1984; 91: 150-6. PMID: 6729211

25. Missmer SA, Eliassen AH, Barbieri RL, Hankinson SE. Endogenous estrogen, androgen, and progesterone concentrations and breast cancer risk among postmenopausal women. J Natl Cancer Inst. 2004; 96 (24): 1856-65. PMID: 15601642

26. Brunicardi FC, Andersen DK, Billiar TR, Dunn DL, Hunter JG, Pollock RE. Schwartz's principles of surgery. 2005. Eight ed.

27. Mehta RR, Valcourt L, Graves J, Green R, Das Gupta TK. Subcellular Concentrations of estrone, estradiol, androstenedione and 17 beta-hydroxysteroid dehydrogenase (17-beta-OH-SDH ) activity in malignant and non-malignant human breast tissues. Int $\mathrm{J}$ Cancer. 1987; 40 (3): 305-8. PMID: 3040598

28. Drafta D, Prişcu A, Neacşu E, Gangură M, Schindler AE, Stroe $\mathrm{E}$, et al. Estradiol and progesterone receptor levels in human breast cancer in relation to cytosol and plasma estrogen level. J Steroid Biochem. 1983; 18 (4): 459-63. PMID: 6834830

29. Hankinson SE, Willett WC, Michaud DS, Manson JE, Colditz $\mathrm{GA}$, Longcope $\mathrm{C}$, et al. Plasma prolactin levels and subsequent risk of breast cancer in postmenopausal women. J Natl Cancer Inst. 1999; 91 (7): 629-34. PMID: 10203283 